第 29 回日本耳科学会総会 · 学術講演会 Young Award 賞

\title{
内視鏡下でのアブミ骨筋反射閾値の検討
}

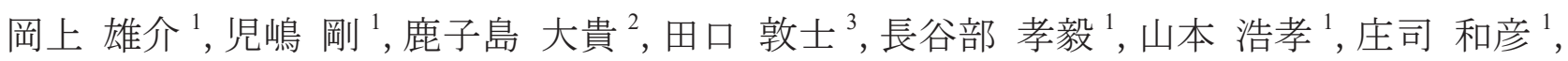
堀 龍介 $^{1}$

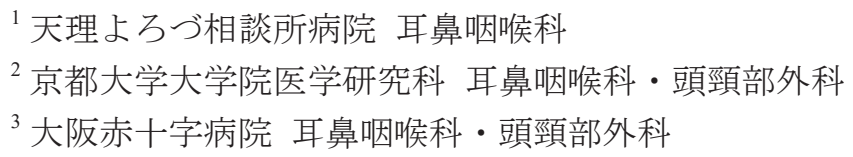

【背景】強大音から蝸牛を防御するアブミ骨筋反射（SR）は，音刺激が閾値を超えると両側の顔面神経核が刺激 され両側性に生じる．検査としてはインピーダンスオージオメトリーによるレフレックス検査があるが，アブミ 骨筋が収縮してアブミ骨の可動が耳小骨や MI joint を逆行に経由して鼓膜まで可動したものを間接的に検出してい るにすぎない．そのため，真の閾值は測定できておらず，実際はさらに小さな音刺激でも SR が生じているはず である. SR を直接観察することができれば，より正確な閾值を評価することができるはずである.

【目的】正確な SR 閾值を測定する方法の開発

【対象と方法】健側耳聴力が正常かつ患側の鼓室に病変を伴わない，局所麻酔下に内視鏡下耳科手術を施行する患 者を対象とする. 術中に健側耳への音刺激にて対側耳に生じるSR を内視鏡下にアブミ骨の可動を直接確認し閾 值の測定を行うままた，鼓室に銀ボール電極を設置し，筋電図を測定することにより，電気生理学的にも閾値を 評価する.

【結果】内視鏡下に SR を直接確認することができた．術前のレフレックス検査による SR 閾値と比べて，内視鏡 下で観察した最小音刺激閾値は低かった．アブミ骨筋筋電図も測定することができ，内視鏡下に観察した閾値と ほぼ同じであった.

【考察】この検討結果は SR のより正確な閾値を測定する方法の開発に寄与する．本検討の臨床応用として，末梢 性顔面神経麻痺の超早期予後診断への活用が挙げられる. SR が検出されれば顔面神経麻痺は回復しやすいとさ れているが，検出されなくても麻瘏が回復することも多く，レフレックス検査では正確な予後診断に限界がある. それは，SRの真の閾值を測定できていないことが関係しており，より正確な閾值を測定できれば，予後診断の精 度も向上するはずである. 今後更なる検討を行っていく.

キーワード：アブミ骨筋反射，内視鏡下，閾値

\section{Endoscopic measurement of the stapedius reflex threshold}

Yusuke Okanoue $^{1}$, Tsuyoshi Kojima ${ }^{1}$, Hiroki Kagoshima ${ }^{2}$, Atsushi Taguchi ${ }^{3}$, Koki Hasebe ${ }^{1}$, Hirotaka Yamamoto ${ }^{1}$, Kazuhiko Shoji ${ }^{1}$, Ryusuke Hori ${ }^{1}$

${ }^{1}$ Department of Otolaryngology, Tenri Hospital; ${ }^{2}$ Department of Otolaryngology-Head and Neck Surgery, Graduate School of Medicine, Kyoto University; ${ }^{3}$ Department of Otolaryngology-Head and Neck Surgery, Osaka Red Cross Hospital 
キースライド

1

実際はさらに小さな音でも アブミ骨筋反射(SR)は起こっている?

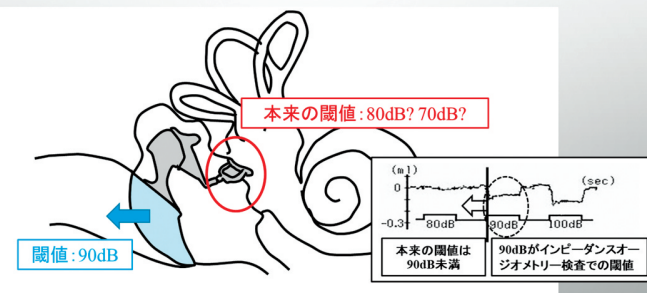

3

目的

O内視鏡下でSRを誘発する正確な最小音刺激閾値の測定評価法の開発

\section{対象}

○健側耳正常(鼓室·鼓膜に病変伴わず、気骨導差なし)で、患側耳の鼓 室に病変を伴わず、骨導聴力に左右差がない

(1) 単純鼓膜穿孔に対し内視鏡下鼓膜形成術(鼓室形成術I型もしくは接 着法)を施行する患者

(2)外リンパ澶に対し内視鏡下内耳悹閉鎖術を施行する患者

(3)外傷性耳小骨離断に対し内視鏡下鼓室形成術を施行する患者

5

方法

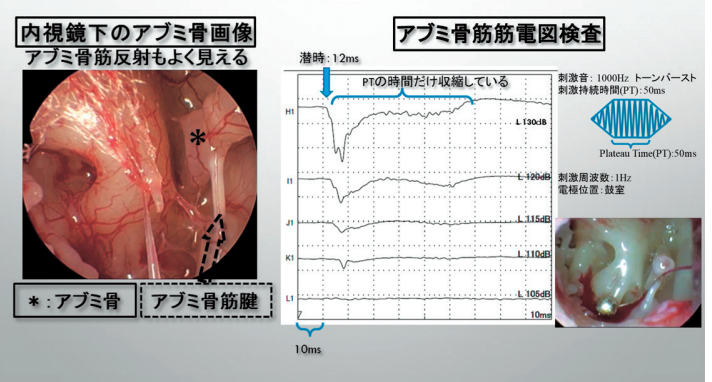

7

結果のまとめ

-内視鏡下評価法

〉SRを観察することができ、その閾值も評価できた

メツチ骨柄の可動を確認できる音の闇值とアブミ骨の可動を確認で きる音の闇値に乘離を認めた

・電気生理学的評価法

〉アブミ骨筋の筋電位を計測でき、SR閾値も評価できた

・内視鏡下・アブミ骨筋筋電図ともにインピーダンスオージオメト

リーでのSRの闇値より低かった

・内視鏡下とアブミ骨筋筋電図でのSR閾値はほぼ同じであった
2

内視鏡下でSRを観察できる

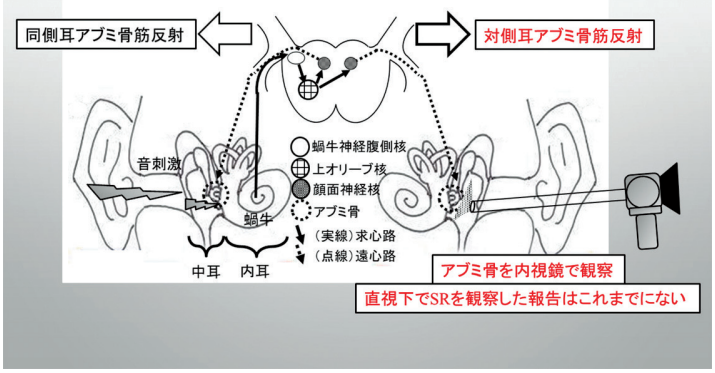

4

\section{方法}

○局所麻酔下での手術·検査

O健側耳への刺激音、音圧を変えていきながら、対側耳(術側)SRを誘発

〉内視鏡下評価法:アブミ骨の可動を内視鏡下で直接確認し最小闌值を測定

〉電気生理学的評価法:アブミ骨筋の筋電図を計測

、鼓室に銀ボール電極を留置(基準電極:乳様突起, 接地電極:上腕)

マアブミ骨筋が収縮する時に発生する筋活動電位を測定

$\checkmark$ 日本光電 誘発電位·筋電図検查装置 MEB-2204ニューロパックで測定

6

結果

内視鏡下とインピーダンスオージオメトリーでのSR閾值比較

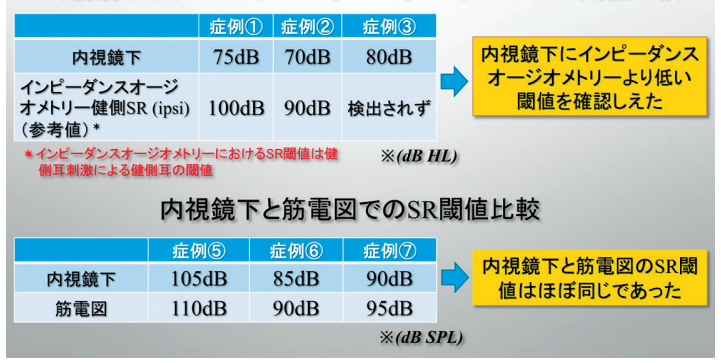

8

\section{顔面神経麻舫の早期予後診断に応用できる}

ENoGでの予後診断

- 側頭骨外の顔面神経機能検査

- Waller変性が側頭骨外まで及ん

でからの診断

・早期予後診断には向かない

\section{SRでの予後診断}

- 側頭骨内の顔面神経機能検査

- Waller変性が側頭骨内で起こった早期 にアブミ骨筋神経は障害される

・早期予後診断に有用のはずだが... > SR検出されると回復予測 $>\mathrm{SR}$ 検出なくても回復することも多い フインピーダンスオージオメトリーでは している 